\title{
SUSTAINABLE DEVELOPMENT IN POLAND IN COMPARISON TO THE EUROPEAN UNION
}

\author{
RAFAL CZYŻYCKI \\ University of Szczecin, POLAND \\ e-mail: rafal.czyzycki@wzieu.pl
}

\begin{abstract}
\begin{tabular}{l|l} 
RECEIVED & 8 May 2018
\end{tabular}
\begin{tabular}{l|l} 
ACCEPTED & 12 September 2018
\end{tabular}

JEL

CLASSIFICATION

018, R11

KEYWORDS sustainable development, measuring of sustainable development

ABSTRACT Sustainable development has been the subject of scientific research for almost half a century. Despite the fact that the term "regional development" was first used in 1972, it still has not been clearly defined. Therefore, various researchers differently perceive the issue of sustainable development, which is still the subject of multiple research articles. On the basis of the Web of Science only, it can be indicated that in 2015, 909 articles were published, which had "sustainable development" in their title, in 2016 there were 1080 of such articles, and in 2017-1039. The subject of this article is to evaluate the importance of sustainable development in Polish regional policy as well as the analysis of its level in comparison with other EU countries in 2016.
\end{abstract}

\section{The issue and importance of sustainable development}

The definition of sustainable development differs significantly from the pure economic definition of sustainable economic growth. The notion was first used in 1972 at the first UN Conference on Environment and Development, where it was stated that "sustainable development is a desired economic development, which does not substantially or irremediably infringe the human living environment, does not lead to biosphere degradation and does not violate 
the laws of nature, economy or culture" (Siekierski, 2013, p. 140). However, the notion of sustainable development was disseminated only owing to the Report of the World Commission on Environment and Development: "Our Common Future", known as the Brundtland Report, which defined sustainable development as the right to satisfy developmental aspirations of the current generation without restricting the rights of future generations to meet their developmental needs. This means that the economic and civilisational development of the present generation should not take place at the expense of exhausting non-renewable resources or destroying the environment, which would result in the reduction of developmental possibilities of future generations. The concept of sustainable development introduces a qualitatively new form of the aware and responsible, individual and social life by way of development along with the environment - social and natural one - taking into account ecological restrictions and social expectations (Skowroński, 2006, p. 51). Sustainable development is understood as the socio-economic growth compatible with the natural environment, realizing social expectations and aspirations in the scope of the perspective of meeting the needs and self-fulfillment (Mazur-Wierzbicka, 2017, pp. 255-256), and the overarching principle of sustainable development is meeting not only ad hoc needs, but also the needs of future generations, aiming at the balance between environmental, economic and social systems (Dembińska-Cyran, 2006, p. 14). Rogall $(2010$, p. 44) claims that "sustainable development aims to ensure that all people living today and future generations have sufficiently high environmental, economic and socio-cultural standards within the strength of the Earth's natural limits, applying the principle of intra-generational and intergenerational justice". However, Bajerowski (1998, see Piontek, 2002, p. 16) indicates that sustainable development is not a state but a process and the proper course of each process is guaranteed by the control and management of different factors. Therefore, the process of sustainable development must be a process of choosing the line of development, based on minimization of losses and maximization of benefits. Managing sustainable development at a macroeconomic level means stimulating production and consumption through technological advances, increase in the efficiency of resources and materials use, integration of socio-economic development with environmental protection as well as adjustment of economic growth to the needs and capabilities of the region (Adamczyk, 2017, p. 8).

The international importance of the issue related to sustainable development is evidenced by the fact that in June 2012 Rio de Janeiro held the United Nations Conference on Sustainable Development. One of its results was the decision of the UN member states concerning the inauguration of the process for developing the set of new Sustainable Development Goals (SDGs). In September 2015, at the United Nations Headquarters in New York the UN Sustainable Development Summit adopted the document "Transforming our world: the 2030 Agenda for Sustainable Development”, which includes 17 SDGs (Resolution, 2015):

- Goal 1. End poverty in all its forms everywhere.

- Goal 2. End hunger, achieve food security and improved nutrition and promote sustainable agriculture.

- Goal 3. Ensure healthy lives and promote well-being for all at all ages.

- Goal 4. Ensure inclusive and equitable quality education and promote lifelong learning opportunities for all.

- Goal 5. Achieve gender equality and empower all women and girls.

- Goal 6. Ensure availability and sustainable management of water and sanitation for all.

- Goal 7. Ensure access to affordable, reliable, sustainable and modern energy for all.

- Goal 8. Promote sustained, inclusive and sustainable economic growth, full and productive employment and decent work for all. 
- Goal 9. Build resilient infrastructure, promote inclusive and sustainable industrialization and foster innovation.

- Goal 10. Reduce inequality within and among countries.

- Goal 11. Make cities and human settlements inclusive, safe, resilient and sustainable.

- Goal 12. Ensure sustainable consumption and production patterns.

- Goal 13. Take urgent action to combat climate change and its impacts.

- Goal 14. Conserve and sustainably use the oceans, seas and marine resources for sustainable development.

- Goal 15. Protect, restore and promote sustainable use of terrestrial ecosystems, sustainably manage forests, combat desertification, and halt and reverse land degradation and halt biodiversity loss.

- Goal 16. Promote peaceful and inclusive societies for sustainable development, provide access to justice for all and build effective, accountable and inclusive institutions at all levels.

- Goal 17. Strengthen the means of implementation and revitalize the global partnership for sustainable development.

\section{The issue of sustainable development in the European Union}

Sustainable development was recognized as a fundamental objective of the European Union in 1990 at the summit in Dublin. In addition, in 1992 the Treaty on the European Union stressed the EU transition towards sustainable development, and the EU's $5^{\text {th }}$ Environment Action Programme for the years 1993-2000 defined basic determinants necessary for effective implementation of the sustainable development strategy involving, among others, adoption of the principle that the consumption of goods by one generation cannot take place at the expense of the successive generation, or the promotion of a rational use of resources and raw materials assuming that their amount is fixed (Kosior, 2008, pp. 206-207). The importance of sustainable development for the EU was also underlined in the Preamble to the Amsterdam Treaty (1997), which states: „determined to promote economic and social progress for their peoples, taking into account the principle of sustainable development and within the context of the accomplishment of the internal market and of reinforced cohesion and environmental protection, and to implement policies ensuring that advances in economic integration are accompanied by parallel progress in other fields" (OJ, 2008, p. 15). In 2001, the Gothenburg summit adopted the EU sustainable development strategy, which included the so called Impact Assessment, i.e. the assessment of the decisions in the context of sustainable development. However, in 2006 the EU Council adopted the Review of the EU Sustainable Development Strategy (EU SDS) - Renewed Strategy, which stressed that its overall aim is "to identify and develop actions to enable the EU to achieve continuous improvement of quality of life both for current and for future generations" (CEU, 2006, p. 3). Sustainable development was also included in three priorities of the EU strategies published on 3 March 2010: Europe 2020: a strategy for smart, sustainable and inclusive growth, which constitutes a long-term socio-economic programme of the EU.

\section{Legal aspects of sustainable development in Poland}

The importance of sustainable development in Poland is reflected in the Constitution of the Republic of Poland, which states: „The Republic of Poland shall safeguard the independence and integrity of its territory and ensure the freedoms and rights of persons and citizens, the security of the citizens, safeguard the national heritage and 
shall ensure the protection of the natural environment pursuant to the principles of sustainable development." (CRP, 1997, art. 5). The second source of law with regard to sustainable development is the Act on Spatial Planning and Development. The law specifies the principles of spatial policy realized by local government units and government administration bodies as well as the scope and procedures in cases of using lands for specific purposes as well as the principles of land-use and building development regarding spatial order and sustainable development as the basis for these activities (The Act, 2003, art. 1.1). The notion of sustainable development was also defined in the Environmental Protection Law, which states that sustainable development "means social and economic development, which integrates political, economic and social activities while maintaining natural balance and permanence of basic natural processes in order to guarantee the possibility of satisfying basic needs of particular communities or citizens of the existing generation and the generations to come." (The Act, 2001, art. 3 par. 50).

\section{Sustainable development in Poland compared to other EU countries}

Literature does not provide one generally applicable system of sustainable development indicators that would allow making direct and automatic comparisons of the level of sustainable development in individual countries (see Bell, Morse, 2008). Regardless of the adopted set of such indicators for comparisons, they should comply with specific standards. The most frequently indicated, minimum requirements with regard to this type of indicators are based on the SMART principle (The Ministry of Regional Development, 2012, pp. 11-12): S - Specific, simple - described in detail, related to specific problems and clearly defined, M - Measurable - measurable when using appropriate tools, A - Available/assessable/acceptable - information needed to measure the indicator is or will be available during the project's implementation at an acceptable cost, $\mathrm{R}$ - Realistic/relevant - possible to realize or accomplish with the available resources, $\mathrm{T}$ - Timebound - a timeframe should be determined for achieving the assumed in the application form indicator's value as well as the frequency of its measurement. The currently binding set of the EU sustainable development indicators directly related to the EU SDS includes 10 thematic areas (fields) and reflects 7 key challenges of the EU SDS. They are: socio-economic development, sustainable production and consumption, social inclusion, demographic changes, public health, climate change and energy, sustainable transport, natural resources, global partnership and good governance. However, a broader set of indicators, describing the current situation of 154 countries in the world and including $99 \%$ of the world's population, that enables detailed comparisons has been made available by the Sustainable Society Foundation (http://www.ssfindex.com). On the basis of the analysis of the published 21 indicators describing the level of sustainable development, it can be assumed that the Polish situation in this scope does not significantly differ from the average situation in all EU countries (see Figure 1).

Poland has a higher level of sustainable development compared to the EU average in such areas as: Safe Sanitation, Education, Income Distribution, Population Growth, Biodiversity, Consumption, Energy Use, Genuine Savings, Employment and Public Debt, whereas a significantly lower level is observed only in the areas of Renewable Energy and Greenhouse Gases. Detailed information concerning the value of particular indicators of sustainable development in Poland compared to the average, maximum and minimum ones in the EU is presented in Table 1. 


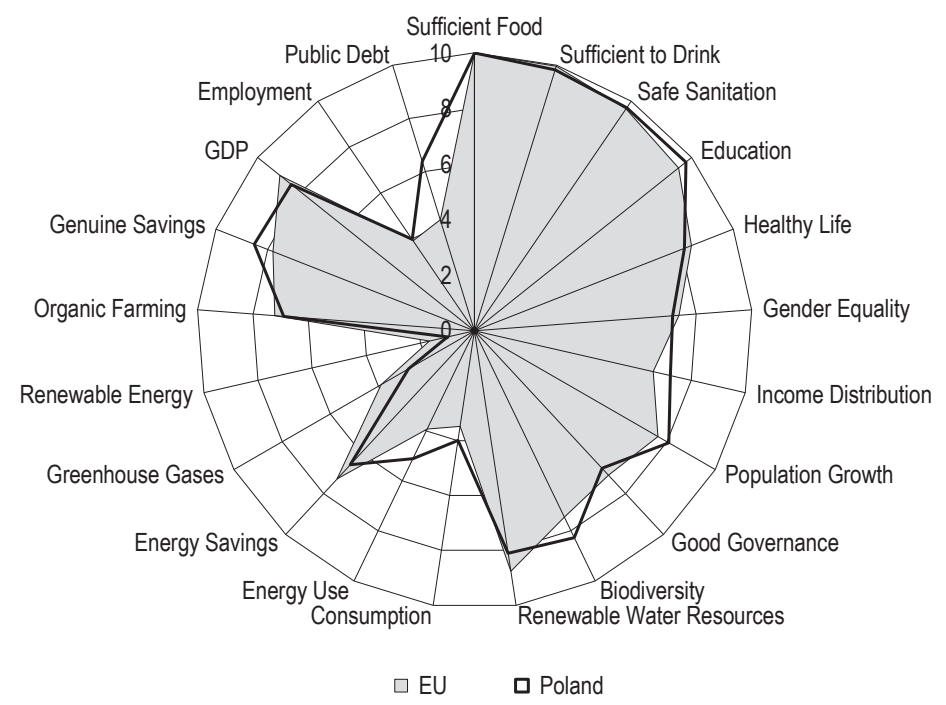

Figure 1. Values of sustainable development indicators in 21 research areas on a scale of 1-10 (10 = sustainable, $1=$ not sustainable)

Source: author's own elaboration.

Table 1. Basic statistics describing the values of 21 indicators of sustainable development in Poland in comparison to the European Union

\begin{tabular}{lcccc}
\hline & & European Union & \multirow{2}{*}{ Poland } \\
\cline { 2 - 3 } & average & max & min & 10.0 \\
\hline Sufficient Food & 10.0 & 10.0 & 10.0 & 9.8 \\
Sufficient to Drink & 10.0 & 10.0 & 9.7 & 9.7 \\
Safe Sanitation & 9.7 & 10.0 & 7.9 & 9.7 \\
Education & 9.4 & 10.0 & 7.7 & 8.1 \\
Healthy Life & 8.4 & 8.8 & 7.7 & 7.2 \\
Gender Equality & 7.4 & 8.5 & 6.7 & 7.2 \\
Income Distribution & 6.6 & 8.9 & 3.4 & 8.1 \\
Population Growth & 7.6 & 9.6 & 3.1 & 6.8 \\
Good Governance & 7.1 & 8.7 & 5.2 & 8.3 \\
Biodiversity & 7.5 & 9.3 & 3.7 & 8.1 \\
Renewable Water Resources & 8.8 & 9.9 & 5.6 & 4.0 \\
Consumption & 3.5 & 6.6 & 1.0 & 5.1 \\
Energy Use & 3.9 & 6.8 & 1.0 & 6.6 \\
Energy Savings & 7.3 & 10.0 & 2.8 & 2.7 \\
Greenhouse Gases & 3.9 & 6.6 & 1.0 & 1.0 \\
Renewable Energy & 1.7 & 3.7 & 1.0 & 6.9 \\
Organic Farming & 7.2 & 9.9 & 1.7 & 8.5 \\
Genuine Savings & 7.8 & 9.3 & 2.0 & 8.4 \\
GDP & 9.0 & 10.0 & 7.3 & 4.0 \\
Employment & 3.9 & 6.1 & 1.0 & 6.4 \\
Public Debt & 4.2 & 9.7 & 1.0 & \\
\hline
\end{tabular}

Source: author's own elaboration. 


\section{Conclusions}

The issue related to sustainable development is still highly relevant despite many years of research. The main problem in this scope remains the lack of a clear definition of sustainable development and, therefore, the lack of general consent how to investigate this development as well as how to make measurements, and which areas of human life should be the subject of particular interest in this scope. However, it should be taken into account that sustainable development is different from socio-economic development or the level of economic prosperity. When analysing the average value of the above-described 21 sustainable development indicators, it can be noted that the highest level of sustainable development is in Denmark, and then in Sweden, Romania, Slovenia and Latvia, and Poland, taking the $12^{\text {th }}$ place, is followed by such EU countries as Germany, the UK, the Netherlands, France or Greece, which occupies the last position.

\section{References}

Adamczyk, J. (2017). Dyfuzja koncepcji zrównoważonego rozwoju i społecznej odpowiedzialności przedsiębiorstw. Marketing I Rynek, $11,5$.

Bell, S., Morse, S. (2008). Sustainability indicators: measuring the immeasurable? Earthscan.

CEU (2006). Review of the EU Sustainable Development Strategy (EU SDS) - Renewed Strategy. Council of the European Union, 10117/06.

Dembińska-Cyran, I. (2006). Sposoby rozwiązywania problemów transportu w zgodzie z zasadami zrównoważonego rozwoju miast (cz. 1). Logistyka, 14.

Kosior, M. (2008). Historyczny rozwój programów działań na rzecz środowiska w Unii Europejskiej. Studia Ecologiae et Bioethicae, 1 , 201-212.

CRP (1997). Constitution of the Republic of Poland of 2nd April 1997. Dz.U, 78 (483).

Mazur-Wierzbicka, E. (2017). Zmiany demograficzne w kontekście zrównoważonego rozwoju - Polska na tle krajów Unii Europejskiej. Analiza komparatywna. Myśl Ekonomiczna i Polityczna, 2 (57), 253-274.

OJ. (2008). Consolidated version of the Treaty of European Union. Official Journal of the European Union, 51.

Piontek, B. (2002). Koncepcja rozwoju zrównoważonego i trwałego Polski. Warszawa: Wydawnictwo Naukowe PWN.

Podręcznik wskaźników. Program Operacyjny Kapitał Ludzki 2007-2013 (2013). Warszawa.

Resolution, A. (2015). A/RES/70/1. Transforming our world: the 2030 agenda for sustainable development. Seventieth United Nations General Assembly.

Rogall, H. (2010). Ekonomia zrównoważonego rozwoju: teoria i praktyka. Poznań: Zysk i S-ka Wydawnictwo.

Siekierski, J. (2013). Strategie rozwoju Polski w latach 1990-2030. Zeszyty Naukowe Małopolskiej Wyższej Szkoły Ekonomicznej w Tarnowie, 1 (22), 133-153.

Skowroński, A. (2006). Zrównoważony rozwój perspektywą dalszego postępu cywilizacyjnego. Problemy Ekorozwoju: studia filozoficzno-sozologiczne, 1 (2), 47-57.

The Act of 27 April 2001 Environmental Protection Law. Journal of Laws No. 62 item 627.

The Act of 27 March 2003. The Spatial Planning and Management. Journal of Laws No. 80 item 717.

Cite this article aS: Czyżycki, R. (2018). Sustainable development in Poland in comparison to the European Union. European Journal of Service Management, 3 (27/1), 47-52. DOI: 10.18276/ejsm.2018.27/1-06. 